\title{
Analisis Pendapatan Usahatani Dan Efisiensi Pemasaran Jamur Merang (Volvariella volvaceae) Di Kecamatan Ajung Kabupaten Jember
}

\author{
Annisa Istifarin Qorina, Henik Prayuginingsih, Syamsul Hadi \\ Fakultas Pertanian Universitas Muhammadiyah Jember \\ E-mail : annisakarinqorina@gmail.com, henik@unmuhjember.ac.id, syamsul.hadi@unmuhjember.ac.id
} Diterima: Desember 2020 ; Dipublikasikan Januari 2021

\begin{abstract}
ABSTRAK
Jamur merang merupakan salah satu komoditas pertanian yang banyak dibudidayakan. Tujuan penelitian: (1) mengukur keuntungan (2) mengukur besar pendapatan (3) menganalisis layak tidaknya kegiatan usahatani (4) mengidentifikasi faktor-faktor yang mempengaruhi pendapatan, dan (5) mengukur tingkat efisiensi saluran pemasaran jamur merang. Metode penelitian menggunakan metode survey, deskriptif, dan kuantitatif. Lokasi penelitian di Kecamatan Ajung Kabupaten Jember. Metode pengambilan sampel menggunakan sampel jenuh sebanyak 19 sampel. Metode pengumpulan data: data primer dan sekunder. Metode analisis data menggunakan analisis keuntungan, pendapatan, $\mathrm{R} / \mathrm{C}$ ratio, regresi linear berganda, dan farmer's share. Hasil penelitian menyimpulkan: (1) Keuntungan yang diperoleh petani jamur merang di Kecamatan Ajung sebesar Rp.1.071.519,54 (2) Pendapatan petani jamur merang di Kecamatan Ajung sebesar Rp. 1.111.688,54 (3) Nilai $\mathrm{R} / \mathrm{C}$ ratio usahatani jamur merang sebesar 2,90 (>1), maka usahatani tersebut layak diusahakan (4) faktor yang berpengaruh positif signifikan terhadap pendapatan usahatani jamur merang yaitu: output harga jual. Faktor yang berpengaruh negatif dan tidak signifikan adalah biaya non tunai sedangkan faktor biaya tunai berpengaruh negatif dan signifikan (5) analisis farmer's share pola saluran pemasaran I tingkat sebesar $87,86 \%$, untuk pola saluran pemasaran II tingkat sebesar $69,11 \%$ maka pola saluran pemasaran I tingkat lebih efisien dibandingkan dengan pola saluran pemasaran II tingkat.
\end{abstract}

Kata Kunci: Pendapatan, Efisiensi, Tataniaga, Jamur Merang

\begin{abstract}
Warm mushroom is one of the more cultivated agricultural properties. The research objectives: (1) measuring income1 (2) measuring the amount of income (3) analyzing the feasibility of farming activities (4) increasing the factors that influence income, and (5) measuring the level of efficiency of marketing of the warm mushroom. The research methods use survey, descriptive, and quantitative methods. Research location at Ajung District, Jember Regency. The sampling method uses a saturated sample of 19 samples. Data collection methods: primary and secondary data. The method of data analysis, income, $R / C$ Ratio, linear multiple regression, and farmer section. The result of the study concluded: (1) The benefits of the warm mushroom farmers in Ajung District were Rp. 1,071,519.54 (2) The income from the warm mushroom farmers at Ajung District was Rp. 1,111,688.54 (3) The value of $R / C$ ratio of warm mushroom farming is 2.90 (>1), then farming is feasible (4) factors that have a significant positive effect on the income of warm mushroom farming, namely: selling price output. The negative and insignificant factor is non-cash costs while the cash cost factor has a negative and significant effect (5) analysis of farmer's share marketing channel pattern I of $87.86 \%$, for the marketing channel pattern II level of $69.11 \%$ then the channel pattern marketing level I is more efficient compared to channel marketing level II level.
\end{abstract}

Keywords: Income, Efficiency, Farming, Warm Mushroom

\section{PENDAHULUAN}

Komoditas hortikultura (tanaman buah-buahan, sayuran, tanaman hias, dan tanaman biofarmasi) mempunyai peluang pasar yang baik mengingat potensi permintaan domestik maupun internasional besar dan nilai ekonominya tinggi. Adanya kemajuan perekonomian, pendidikan, 
peningkatan pemenuhan untuk kesehatan dan lingkungan, serta dukungan dari berbagai pihak menyebabkan permintaan produk hortikultura semakin meningkat.

Kontribusi hortikultura terhadap manusia dan lingkungan juga cukup besar. Manfaat produk hortikultura bagi manusia diantaranya adalah sebagai sumber pangan dan gizi, pendapatan keluarga, pendapatan negara, sedangkan bagi lingkungan adalah rasa estetikanya, konversi genetik sekaligus penyangga kelestarian alam (Samadi, 1995). Salah satu tumbuhan hortikultura yang berkontribusi dalam hal memenuhi kebutuhan gizi manusia bahkan pendapatan keluarga adalah tanaman jamur.

Pada awalnya, pemenuhan kebutuhan manusia terhadap jamur hanya mengandalkan kemurahan alam. Jamur hanya tumbuh secara alami pada musim hujan. Inisiatif pembudidayaan jamur dilakukan saat kebutuhan terus meningkat, sedangkan persediaan di alam terbatas. Berkat pengamatan dan ketelitian mempelajari cara hidupnya, manusia berhasil membudidayakan jamur untuk memenuhi kebutuhan yang meningkat setiap saat (Tim Karya Tani Mandiri, 2010).

Jamur merupakan salah satu komoditas yang mempunyai harapan di masa depan, mengingat permintaan pasar cukup tinggi sedangkan produksi rendah. Singapura misalnya, membutuhkan 100 ton jamur merang setiap bulan dan Malaysia membutuhkan jamur merang sekitar 15 ton tiap minggunya. Kebutuhan jamur merang di pasaran dalam negeri juga mempunyai prospek yang sangat cerah. Kebutuhan jamur merang untuk Jakarta, Bogor, Sukabumi, Bandung, dan sekitarnya rata-rata 15 ton setiap harinya (Mayun, 2007).

Budidaya jamur merang mempunyai umur panen yang relatif singkat yaitu sekitar satu bulan sampai dengan tiga bulan sehingga perputaran modal yang ditanam pada usaha ini berlangsung cepat. Bahan untuk produksi jamur merang mudah didapat dan pengusahanya tidak memerlukan lahan yang luas. Jamur merang dapat memberikan lebih banyak kesempatan kerja dalam upaya peningkatan ekonomi masyarakat petani, sehingga dapat meningkatkan taraf hidup petani dan kesejahteraan petani secara umum (Hagutami, 2001).

Kabupaten Jember merupakan salah satu daerah yang sedang memulai perkembangan budidaya jamur merang. Budidaya jamur merang dipilih karena jamur ini memiliki prospek yang baik, bernilai ekonomi tinggi dan teknik budidaya yang tidak terlalu rumit, bahan baku mudah didapatkan, tenaga kerja tersedia air yang melimpah dan agroklimat yang mendukung.

Ada beberapa kecamatan yang memiliki usaha jamur merang di Kabupaten Jember, antara lain Kecamatan Wuluhan, Kecamatan Silo, Kecamatan Ajung, Kecamatan Rambipuji, Kecamatan Balung, Kecamatan Panti dan Kecamatan Patrang. Kecamatan Ajung merupakan salah satu daerah dimana budidaya jamur merang mulai mengalami penurunan. Menurut data, Kecamatan Ajung mengalami penurunan produksi sebesar 28,279 kwintal dari tahun 2016 dan 2017. Untuk luas lahan menurun sekitar 490 ha.

Usahatani dianggap berhasil jika menguntungkan. Beberapa ahli berpendapat bahwa pendapatan berbeda dengan keuntungan. Pendapatan diartikan dengan selisih penerimaan dengan biaya tunai. Biaya tunai adalah biaya yang benar-benar dikeluarkan untuk membayar faktor produksi, contoh tenaga kerja dari luar keluarga maupun sewa lahan. Sedangkan keuntungan adalah selisih antara penerimaan dengan biaya total, baik biaya tunai maupun biaya non tunai. Biaya non tunai yang dimaksud adalah biaya yang diperhitungkan sebagai balas jasa atas penggunaan faktor produksi oleh keluarga contohnya adalah biaya tenaga kerja dalam keluarga, sewa lahan milik sendiri dan penyusutan alat. Dengan adanya perbedaan pendapat tersebut, peneliti tertarik ingin mengetahui besar pendapatan dan keuntungan usahatani jamur merang, kelayakan usaha, faktor yang mempengaruhi, dan tingkat efisiensi pemasaran jamur merang di Kecamatan Ajung Kabupaten Jember. Penelitian ini bertujuan untuk mengukur besar keuntungan yang diperoleh dari usahatani jamur merang di Kecamatan Ajung Kabupaten Jember, mengukur besar pendapatan yang diperoleh dari usahatani jamur merang di Kecamatan Ajung Kabupaten Jember, menganalisis layak tidaknya kegiatan usahatani jamur merang di Kecamatan Ajung Kabupaten Jember dilihat dari nilai R/C Ratio dan mengidentifikasi faktor-faktor yang mempengaruhi pendapatan usahatani jamur merang di Kecamatan Ajung Kabupaten Jember. 


\section{METODE PENELITIAN}

Metode yang digunakan dalam rencana penelitian ini adalah metode deskriptif dan metode analisis. Metode deskriptif yaitu suatu metode dalam meneliti status sekelompok manusia, suatu objek, suatu kondisi, suatu sistem pemikiran ataupun suatu peristiwa pada masa sekarang. Tujuannya adalah untuk membuat deskripsi, gambaran, atau lukisan secara sistematis, faktual, dan akurat mengenai fakta-fakta, sifat-sifat serta hubungan antara fenomena yang diselidiki (Nazir, 1985 dalam Taufani, 2014)

Untuk menguji hipotesis pertama yaitu analaisis keuntungan adalah selisih dari total penerimaan dengan biaya yang dikeluarkan, yang dapat diformulasikan sebagai berikut:

$$
\begin{array}{ll}
\pi & =\mathrm{TR}-\mathrm{TC} \\
\mathrm{TR} & =(\mathrm{Py} . \mathrm{Y})-(\mathrm{VC}+\mathrm{FC})
\end{array}
$$

Pengujian hipotesis kedua tentang Pendapatan usahatani dibedakan menjadi dua, yaitu pendapatan atas biaya tunai (pendapatan tunai) dan pendapatan atas biaya total (pendapatan total). Pendapatan merupakan hasil pengurangan antara penerimaan dengan biaya. Penerimaan adalah perkalian antara produksi yang diperoleh dengan harga jual.

Pendapatan usahatani dirumuskan dalam persamaan matematik sebagai berikut:

$$
\text { Pendapatan }=\pi+\text { Biaya non tunai }
$$

Berdasarkan hipotesis ketiga yaitu Untuk mengukur efisiensi usahatani dapat diketahui dari perbandingan antara penerimaan dengan biaya yang dikeluarkan (R/C). Secara matematik, hal ini dapat dituliskan sebagai berikut (Soekartawi, 1995):

$$
\begin{array}{ll}
\mathrm{a} & =\mathrm{R} / \mathrm{C} \\
\mathrm{TR} & =(\mathrm{Py} \cdot \mathrm{Y})-(\mathrm{VC}+\mathrm{FC})
\end{array}
$$

Berdasarkan hipotesis keempat Untuk menganalisis faktor-faktor yang mempengaruhi pendapatan digunakan analisis regresi linear berganda yang secara matematik dirumuskan sebagai berikut (Soekartawi, 1987):

$$
\mathrm{Y}=\alpha \mathrm{X}_{1}^{\beta 1} \mathrm{X}_{2}^{\beta 2} \mathrm{X}_{3}^{\beta 3} \ldots . . \mathrm{Xn}^{\beta \mathrm{n}}+\varepsilon
$$

Untuk keperluan analisis maka persamaan di atas dirubah ke dalam persamaan regresi linear sebagai berikut:

$$
\operatorname{Ln} \mathrm{Y}=\operatorname{Ln} \alpha+\mathrm{b}_{1} \operatorname{Ln} \mathrm{X}_{1}+\mathrm{b}_{2} \operatorname{Ln} \mathrm{X}_{2}+\mathrm{b}_{3} \operatorname{Ln} \mathrm{X}_{3} \ldots . .+\mathrm{b}_{\mathrm{n}} \operatorname{Ln} \mathrm{Xn}+\mathrm{e}
$$

Analisis efisiensi pemasaran jamur merang dapat dilihat dari nilai Farmer's Share. Analisis efisiensi pemasaran jamur merang pada penelitian ini adalah perhitungan yang dilakukan untuk melihat efisiensi dari saluran pemasaran yang terjadi pada proses pemasaran jamur merang dari petani hingga ke konsumen akhir. Analisis farmer's share digunakan untuk melihat tingkat efisiensi pemasaran jamur merang. Farmer's Share merupakan perbandingan harga yang diterima petani dengan harga yang diterima konsumen dan dinyatakan dalam persentase. Pedagang pengecer melakukan penjualan jamur merang segar langsung kepada konsumen akhir. Farmer's Share dirumuskan dalam persamaan matematik sebagai berikut:

$$
\mathrm{FS}=\frac{\operatorname{Pf}}{\operatorname{Pr}} \times 100 \%
$$

\section{HASIL DAN PEMBAHASAN}

Hasil Analisis Rata-Rata Keuntungan Per 10 Rak/Bulan Usahatani Jamur Merang di Kecamatan Ajung Kabupaten Jember

\begin{tabular}{clcr}
\hline No. & \multicolumn{1}{c}{ Uraian } & Satuan & \multicolumn{1}{c}{ Nilai (Rp) } \\
\hline 1 & Produksi Jamur Merang & $\mathrm{Kg}$ & 103,69 \\
2 & Harga Jual Jamur Merang & $\mathrm{Rp} / \mathrm{kg}$ & $15.772,15$ \\
3 & Total Penerimaan & $\mathrm{Rp}$ & $1.635 .414,67$ \\
4 & Total Biaya / TC & $\mathrm{Rp}$ & $563.895,13$ \\
\hline & Keuntungan & $\mathbf{R p}$ & $\mathbf{1 . 0 7 1 . 5 1 9 , 5 4}$ \\
\hline
\end{tabular}

Sumber : Analisis Data Primer, 2019 
Tabel diatas menunjukkan bahwa usahatani jamur merang di Kecamatan Ajung Kabupaten Jember menguntungkan karena total penerimaan yang didapat oleh petani lebih besar daripada biaya yang dikeluarkan petani. Penerimaan yang didapat petani untuk 10 rak per bulan sebesar Rp. 1.635.414,67, dan total biaya atau total cost (TC) yang dikeluarkan sebesar Rp. 563.895,13.

Keuntungan yang diperoleh petani jamur merang sangatlah tinggi untuk 10 rak/bulan yaitu sebesar Rp. 1.071.519,54. Menurut hasil penelitian Taufani (2014), menyebutkan bahwa keuntungan yang didapat dalam usahatani jamur merang dengan skala 100 log sebesar Rp. 2.673.562. Hasil analisis tersebut menunjukkan bahwa usahatani jamur merang di Kecamatan Ajung Kabupaten Jember sangat menguntungkan. Hal itu dapat dilihat dari nilai keuntungan yang tinggi. Sebagian besar petani jamur merang di Kecamatan Ajung Kabupaten Jember masih menggunakan alat-alat tradisional, dan tidak memiliki biaya perawatan dalam proses pertumbuhan jamur merang, dan tenaga kerja yang digunakan sangatlah sedikit sehingga dapat meminimalisir biaya yang dikeluarkan. Total biaya yang dikeluarkan oleh para petani jamur merang lebih kecil dibandingkan penerimaan yang didapat oleh petani. Selain itu, harga jamur merang sangat jarang sekali mengalami proses penurunan harga, sehingga penerimaan yang diterima petani cukup besar.

Hasil Analisis Rata-Rata Pendapatan Per 10 Rak/Bulan Usahatani Jamur Merang di Kecamatan Ajung Kabupaten Jember

\begin{tabular}{rlrr}
\hline No. & \multicolumn{1}{c}{ Uraian } & Satuan & \multicolumn{1}{c}{$\begin{array}{c}\text { Nilai } \\
(\mathbf{R p})\end{array}$} \\
\hline 1 & Produksi Jamur Merang & $\mathrm{kg}$ & 103,69 \\
2 & Harga Jual Jamur Merang & $\mathrm{Rp} / \mathrm{kg}$ & $15.772,15$ \\
3 & Total Penerimaan & $\mathrm{Rp}$ & $1.635 .414,67$ \\
4 & Total Biaya / TC & $\mathrm{Rp}$ & $563.895,13$ \\
5 & Keuntungan & $\mathrm{Rp}$ & $1.071 .519,54$ \\
6 & Biaya Non Tunai & $\mathrm{Rp}$ & $40.169,00$ \\
\hline & Pendapatan & $\mathbf{R p}$ & $\mathbf{1 . 1 1 1 . 6 8 8 , 5 4}$ \\
\hline
\end{tabular}

Sumber : Analisis Data Primer, 2019

Tabel diatas menunjukkan bahwa rata-rata produksi jamur merang sebesar 103,69 Kg. Ratarata penerimaan $10 \mathrm{rak} /$ bulan sebesar Rp. 1.635.414,67. Rata-rata total biaya atau total cost (TC) yang dikeluarkan oleh petani selama satu kali proses produksi sebesar Rp. 563.895,13 dengan total tingkat keuntungan sebesar Rp. 1.071.519,54. Rata-rata biaya non tunai dalam 10 rak/bulan yaitu Rp.40.169,00, maka tingkat pendapatan yang dihasilkan oleh petani jamur merang sebesar Rp. 1.111.688,54. Tujuan konversi menjadi $10 \mathrm{rak} / \mathrm{bulan}$ agar memudahkan para pelaku usaha untuk memperkirakan pendapatan yang diperoleh dalam berusahatani jamur merang.

Analisis pendapatan jamur merang di Kecamatan Ajung memperoleh hasil yang cukup tinggi. Hasil tersebut didukung dari hasil penelitian terdahulu oleh Nurfitasari (2017) yang mengkonversikan dalam luasan $38,67 \mathrm{~m}^{2}$ (rata-rata total luas rak setiap kumbung). Pendapatan yang diperoleh petani selama satu tahun (8 kali proses produksi) sebesar Rp. 6.990.010.

Rata-Rata Biaya Per 10 Rak/Bulan pada Usahatani Jamur Merang di Kecamatan Ajung Kabupaten Jember

\begin{tabular}{|c|c|c|c|c|c|c|}
\hline \multirow[b]{2}{*}{ No } & \multirow[b]{2}{*}{ Rincian Biaya } & \multirow[b]{2}{*}{ Satuan } & \multirow[b]{2}{*}{ Volume } & \multirow[b]{2}{*}{ Biaya } & \multicolumn{2}{|c|}{ Nilai } \\
\hline & & & & & $\begin{array}{c}\text { Rata-Rata } \\
\text { (Rp) }\end{array}$ & $\begin{array}{c}\text { Persentase } \\
(\%)\end{array}$ \\
\hline \multirow[t]{4}{*}{1} & Biaya Tetap & & & & & \\
\hline & a. Biaya Penyusutan Alat & Ls & 1 & $60.338,06$ & $60.338,06$ & 10,70 \\
\hline & c. Sewa Lahan & $\mathrm{m} 2$ & 60,32 & $15.752,68$ & $15.752,68$ & 2,79 \\
\hline & Total Biaya Tetap (TFC) & & & & $76.090,74$ & 13,49 \\
\hline \multirow[t]{5}{*}{2} & Biaya Variabel & & & & & - \\
\hline & a. Biaya Bibit & Baglog & 2 & 34.956 & $67.548,21$ & 11,99 \\
\hline & b. Biaya Jerami & Pick Up & 0,61 & 195.054 & $118.219,30$ & 20,96 \\
\hline & c. Biaya Kapur & Sak & 0,62 & 6.915 & $4.370,48$ & 0,78 \\
\hline & & & $P$ & $N: 2459-9$ & 1 E-ISSN:252 & 0570 \\
\hline
\end{tabular}




\begin{tabular}{lccrrr} 
d. Biaya Bekatul & $\mathrm{Kg}$ & 13 & 4.847 & $65.423,98$ & 11,60 \\
e. Biaya Kayu Bakar & Kubik & 0,9 & 55.387 & $49.420,76$ & 8,76 \\
f. Biaya Tenaga Kerja & Orang & 1 & 182.786 & $182.785,67$ & 32,41 \\
\hline Total Biaya Variabel (TVC) & & & & $\mathbf{4 8 7 . 8 0 4 , 4 0}$ & 86,51 \\
\hline \multicolumn{1}{c}{ Total Biaya (TC) } & & & & $\mathbf{5 6 3 . 8 9 5 , 1 4}$ & $\mathbf{1 0 0 , 0 0}$ \\
\hline
\end{tabular}

Sumber: Analisis Data Primer, 2019.

Berdasarkan Tabel diatas, rata-rata biaya yang dikeluarkan oleh para petani jamur merang di Kecamatan Ajung Kabupaten Jember sebesar Rp. 563.895,14/10 rak dalam satu kali produksi yang terdiri dari biaya tetap dan biaya variabel. Biaya tetap yang dikeluarkan petani sebesar Rp. 76.090,73 dengan nilai persentase sebesar $13,49 \%$ dari total biaya. Biaya tetap terdiri dari pengeluaran untuk penyusutan dan sewa lahan milik sendiri maupun sewa lahan milik orang lain. Rata-rata total biaya variabel yang dikeluarkan oleh petani jamur merang selama satu kali proses produksi sebesar Rp. 487.804 dengan nilai persentase sebesar $86,51 \%$ dari total biaya.

Biaya variabel pada usahatani jamur merang di Kecamatan Ajung Kabupaten Jember terdiri dari biaya bibit, jerami, kapur, bekatul, kayu bakar dan tenaga kerja. Biaya bibit merupakan biaya yang dikeluarkan untuk pembelian bibit yang akan disebar pada media tanam jamur merang di setiap rak. Biaya jerami adalah biaya yang digunakan untuk pembelian jerami sebagai media tanam jamur merang. Jamur merang tumbuh pada jerami, sehingga para petani menggunakan jerami sebagai media tanam dan tidak menggunakan alternatif media lainnya. Biaya kayu digunakan untuk proses pembelian kayu yang digunakan sebagai penunjang pasteurisasi atau pengopenan setelah jerami telah dimasukkan kedalam kumbung.

Biaya tenaga kerja usahatani jamur merang digunakan sebagai upah dalam penggunaan tenaga kerja selama proses usahatani jamur merang berlangsung. Alokasi biaya pada usahatani jamur merang per 10 rak setiap satu kali produksi (1 bulan) di Kecamatan Ajung Kabupaten Jember menunjukkan penggunaan biaya terbesar adalah biaya tenaga kerja yaitu sebesar Rp. 182.785,67 dengan persentase $32,41 \%$.

Nilai efisiensi biaya usahatani jamur merang di Kecamatan Ajung Kabupaten Jember dilakukan perhitungan dengan menggunakan analisis $\mathrm{R} / \mathrm{C}$ ratio. Secara rinci disajikan pada Tabel berikut

\section{Hasil Analisis R/C ratio Per 10 Rak/Bulan Usahatani Jamur Merang di Kecamatan Ajung Kabupaten Jember}

\begin{tabular}{clcr}
\hline No. & Uraian & Satuan & \multicolumn{2}{c}{$\begin{array}{c}\text { Nilai } \\
(\mathbf{R p})\end{array}$} \\
\hline 1 & Total Penerimaan & $\mathrm{Rp}$ & $1.635 .414,67$ \\
2 & Total Biaya / TC & $\mathrm{Rp}$ & $563.895,13$ \\
\hline & R/C ratio & & $\mathbf{2 , 9 0}$ \\
\hline
\end{tabular}

Sumber : Analisis Data Primer, 2019.

Tabel diatas menunjukkan bahwa nilai $\mathrm{R} / \mathrm{C}$ ratio sebesar 2,90 dimana angka tersebut lebih besar dari satu (>1), artinya setiap pengeluaran biaya sebesar Rp.1.000 maka akan diperoleh keuntungan sebesar Rp. 2.900. Hal tersebut dapat diartikan bahwa usahatani jamur merang di Kecamatan Ajung Kabupaten Jember sangatlah efisien, sehingga usahatani jamur merang tersebut sangat layak diusahakan.

Berdasarkan penelitian Taufani (2014) menunjukkan nilai R/C yang dihasilkan per $100 \mathrm{log}$ sebesar 1,84. Arti dari nilai R/C adalah bahwa untuk setiap Rp. 1.000 biaya yang dikeluarkan untuk proses produksi usahatani jamur merang akan memberikan tingkat penerimaan sebesar Rp. 1.840. Dengan demikian besarnya nilai R/C yang didapat lebih dari 1 (>1) maka usahatani jamur merang efisien.

Analisis faktor-faktor yang mempengaruhi pendapatan usahatani jamur merang di Kecamatan Ajung Kabupaten Jember dilakukan dengan menggunakan analisis regresi linier berganda. Dimana pendapatan $(\mathrm{Rp})$ sebagai variabel terikat/dependent variable $(\mathrm{Y})$, sedangkan output $\left(\mathrm{X}_{1}\right)$ harga output $\left(\mathrm{X}_{2}\right)$, biaya non tunai $\left(\mathrm{X}_{3}\right)$ dan biaya tunai $\left(\mathrm{X}_{4}\right)$ sebagai variabel 
bebas/independent variable. Penentuan variabel tersebut adalah untuk mengetahui seberapa besar variabel atau faktor-faktor yang mempengaruhi pendapatan usahatani jamur merang.

Berdasarkan Tabel analisis regresi linear berganda terhadap faktor-faktor yang mempengaruhi pendapatan usahatani jamur merang di Kecamatan Ajung Kabupaten Jember, disajikan bahwa F-hitung sebesar 601,209 dengan tingkat signifikansi 0,000 hal ini dapat diartikan bahwa secara keseluruhan variabel bebas kecuali harga jual berpengaruh nyata terhadap variabel terikat yaitu tingkan pendapatan usahatani jamur merang di Kecamatan Ajung Kabupaten Jember. Hasil analisis juga menunjukkan koefisien deterinasi $\left(\mathrm{R}^{2}\right)$ sebesar 0,994 menunjukkan bahwa semua faktor mempunyai pengaruh terhadap tingkat pendapatan usahatani jamur merang sebesar 99,4\%, sehingga nilai $0,6 \%$ yang lainnya disebabkan oleh faktor lain yang tidak masuk dalam model.

Analisis Regresi Linier Berganda Faktor-Faktor yang Mempengaruhi Pendapatan

\begin{tabular}{|c|c|c|c|c|c|c|}
\hline \multicolumn{2}{|c|}{ Variabel } & $\begin{array}{c}\text { Paramete } \\
\mathbf{r}\end{array}$ & \begin{tabular}{|c|} 
Koefisien \\
Regresi \\
\end{tabular} & $\begin{array}{c}\text { Std. } \\
\text { Error }\end{array}$ & t stat & Sig. \\
\hline Konstanta & $\mathrm{Y}$ & $\mathrm{b}_{0}$ & $-0,501$ & 1,048 & $1,467^{\mathrm{ns}}$ & 0,604 \\
\hline Output & $\mathrm{X}_{1}$ & $\mathrm{~b}_{1}$ & 1,518 & 0,035 & $23,578^{* * *}$ & 0,000 \\
\hline Harga Jual & $\mathrm{X}_{2}$ & $\mathrm{~b}_{2}$ & 1,455 & 0,116 & $3,687^{* * * *}$ & 0,000 \\
\hline $\begin{array}{l}\text { Biaya Non } \\
\text { Tunai }\end{array}$ & $\mathrm{X}_{3}$ & $\mathrm{~b}_{3}$ & $-0,002$ & 0,002 & $2,713^{\text {ns }}$ & 0,331 \\
\hline Biaya Tunai & $X_{4}$ & $\mathrm{~b}_{4}$ & $-0,508$ & 0,037 & -7 & 0,000 \\
\hline Multiple R & & $\mathrm{R}$ & 0,997 & & & \\
\hline R Square & & $\mathrm{R}^{2}$ & 0,994 & & & \\
\hline $\begin{array}{l}\text { Adjusted R } \\
\text { Square }\end{array}$ & & $\overline{\mathrm{R}}^{2}$ & 0,993 & & & \\
\hline Standard Error & & $\mathrm{Se}$ & 0,031 & & & \\
\hline F-ratio & & $\mathrm{F}$ & 601,209 & & & 0,000 \\
\hline Observasi & & $\mathrm{N}$ & 19 & & & \\
\hline
\end{tabular}

Keterangan : Pengujian hipotesis menggunakan uji-t satu arah, dimana ${ }^{* * *}$ menyatakan signifikan masing-masing pada tingkat kepercayaan $99 \%$, ns: tidak signifikan.

Sumber : Analisis Data Primer, 2019.

Sesuai dengan Tabel, maka faktor yang mempengaruhi pendapatan usahatani jamur merang dapat dibagi menjadi tiga bagian: (1) Faktor-faktor yang berpengaruh positif dan signifikan terhadap pendapatan adalah output dan harga jual (2) Faktor-faktor yang berpengaruh negatif dan signifikan terhadap pendapatan usahatani jamur merang adalah biaya tunai, dan (3) faktor-faktor yang berpengaruh negative dan tidak signifikan adalah biaya non tunai. Berdasarkan hasil analisis regresi linear berganda usahatani jamur merang, maka persamaan fungsi dapat dirumuskan sebagai berikut:

$$
\ln Y=-0,501+1,518 \ln X_{1}+1,455 \ln X_{2}-0,002 \ln X_{3}-0,508 \ln X_{4}
$$

Persamaan linier tersebut dimasukkan sehingga fungsi pendapatan usahatani jamur merang sebagai berikut:

$$
\mathrm{Y}=0,605 X_{1}^{1,518} X_{2}^{1,455} X_{3}^{-0,002} X_{4}^{-0,508}
$$

Berdasarkan hasil analisis regresi terlihat bahwa pendapatan jamur merang dipengaruhi oleh faktor; (1) output, (2) harga jual, (3) biaya non tunai, dan (4) biaya tunai. Hal ini dapat dilihat dari nilai F-hitung $(=601,209)$ sangat signifikan pada taraf uji $1 \%$, maka $\mathrm{H}_{0}$ ditolak dan $\mathrm{H}_{\mathrm{a}}$ diterima.

Dilihat dari nilai koefisien determinasi $\left(\mathrm{R}^{2}\right)$ sebesar 0,994 menunjukkan bahwa variabel bebas yang dimasukkan ke dalam model dapat menjelaskan variasi variabel terikat (pendapatan usahatani jamur merang) secara baik sekitar 99,4\%, sedangkan 0,6\% dijelaskan oleh variabel lain yang tidak termasuk ke dalam model, misalnya jumlah produksi yang belum memenuhi permintaan pasar. Hal itu disebabkan oleh jumlah rak yang relatif sedikit.

Adapun pengaruh masing-masing faktor terhadap pendapatan usahatani jamur merang di Kecamatan Ajung Kabupaten Jember dapat dijelaskan sebagai berikut: 


\section{1. $\quad$ Faktor Output $\left(\mathbf{X}_{1}\right)$}

Faktor output atau produksi usahatani jamur merang menunjukkan adanya hubungan positif sebesar 1,518 signifikan pada taraf kepercayaan 99\%. Artinya semakin tinggi tingkat produksi usahatani jamur merang maka tingkat pendapatan yang diperoleh petani semakin tinggi. Secara ekonomis menunjukkan bahwa setiap peningkatan roduksi sebesar $1 \%$ akan mengakibatkan tingat pendapatan petani naik sebesar $1,518 \%$. Dalam kondisi seperti ini petani jamur merang masih dapat melakukan peningkatan produksi karena pertimbangan hasil yang berpengaruh positif.

\section{Faktor Harga Output $\left(\mathbf{X}_{2}\right)$}

Menurut hasil analisis regresi linear berganda, faktor harga berpengaruh positif dan signifikan pada taraf kepercayaan $99 \%$ dengan nilai koefisien regresi sebesar 1,455. Artinya semakin tinggi harga jual hasil produksi, maka pendapatan akan meningkat tidak nyata secara statistik. Dalam arti ekonomi setiap kenaikan $1 \%$ harga jual produksi, maka pendapatan akan bertambah sebesar Rp. 1455. Pengaruh positif dan tidak signifikan dimaksudkan agar petani jamur merang berupaya memperbaiki kualitas hasil panen jamur agar harganya semakin meningkat.

\section{Faktor Biaya Non Tunai $\left(\mathbf{X}_{3}\right)$}

Faktor biaya non tunai berpengaruh negatif dan tidak signifikan dengan nilai koefisien regresi sebesar $-0,002$. Artinya setiap penambahan biaya non tunai sebesar $1 \%$ maka akan menurunkan tingkat pendapatan sebesar $0,002 \%$. Hal ini menunjukkan bahwa dengan menambah atau mengurangi biaya non tunai (seperti tenaga kerja dalam keluarga, dan sewa lahan milik sendiri) berpengaruh negatif terhadap tingkat pendapatan petani jamur merang.

\section{Faktor Biaya Tunai $\left(\mathrm{X}_{4}\right)$}

Faktor biaya tunai berpengaruh negatif dan signifikan terhadap pendapatan usahatani jamur merang dengan nilai koefisien regresi sebesar $-0,508$ pada taraf uji $99 \%$. Artinya, setiap penambahan biaya tunai sebesar $1 \%$ maka akan mengurangi tingkat pendapatan usahatani jamur merang sebesar $0,508 \%$ dengan asumsi variabel-variabel lain dianggap konstan. Dalam hal ini, petani tidak memungkinkan untuk menambah biaya tunai karena dapat mengurangi tingkat pendapatan yang diperoleh petani jamur merang.

Saluran pemasaran jamur merang di Kecamatan Ajung Kabupaten Jember dilakukan melalui dua saluran, yaitu:

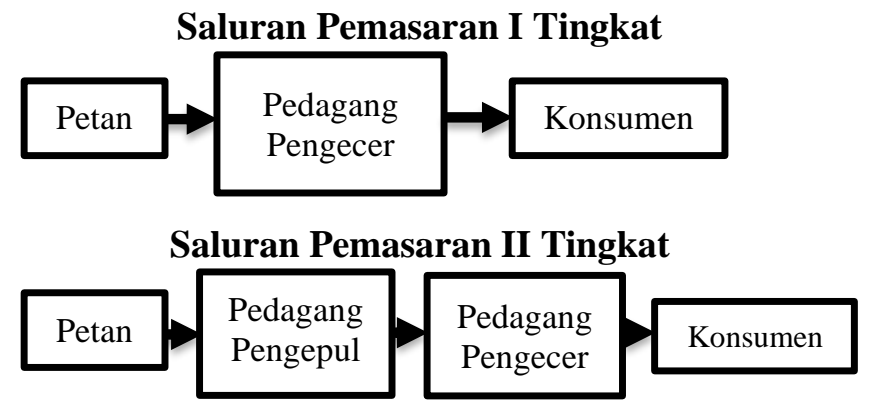

Saluran pemasaran I tingkat dilakukan oleh beberapa petani yang menjual hasil panennya ke pedagang pengecer. Untuk penentuan harga jual, petani dan pedagang pengecer melakukan negosiasi harga sesuai dengan kondisi jamur merang yang akan dipasarkan. Para petani lebih memilih untuk menjual hasil panennya kepada pedagang pengecer dikarenakan jumlah atau kuantitas jamur merang yang mereka produksi sedikit, sehingga para petani tidak menjual hasil panennya langsung kepada para konsumen.

Saluran pemasaran II tingkat dilakukan oleh beberapa patani jamur yang memiliki banyak kumbung karena hasil produksi lebih banyak dibandingkan dengan petani di pola saluran I tingkat. Para petani jamur merang menjual hasil produksinya ke pedagang pengepul supaya mereka mendapatkan harga yang cukup tinggi, karena para petani tidak dapat menentukan harga jual akan tetapi petani menerima harga pembelian yang telah ditetapkan oleh pedagang pengepul atau tengkulak. Hampir sebagian besar para petani jamur di Kcematan Ajung menggunakan saluran II tingkat, karena para petani merasa bahwa menjual hasil produksi jamur merang kepada para pengepul atau tengkulak adalah cara yang paling mudah dan memiliki risiko kerugian yang kecil. 
Pengepul di Kecamatan Ajung hanya terdapat di Desa Mangaran. Sehingga para petani dari desa lain menjual hasilnya ke para pengepul yang masih berada di lingkup Kecamatan Ajung. Para petani menjual hasil produksinya menggunakan keranjang berisi $25 \mathrm{~kg}$, sehingga proses pengemasan dilakukan oleh pengepul. Pengepul atau tengkulak menjual kembali jamur tersebut kepada konsumen setelah melakukan proses pengemasan menggunakan kantong plastik dengan berat $0.5 \mathrm{~kg}$.

Hasil Analisis Farmer's Share Saluran I Tingkat

\begin{tabular}{ccrrr} 
No & Nama & $\begin{array}{c}\text { Harga di Tingkat Petani } \\
(\mathbf{R p} / \mathbf{k g})\end{array}$ & $\begin{array}{c}\text { Harga di Tingkat Konsumen } \\
(\mathbf{R p / k g})\end{array}$ & $\begin{array}{c}\text { Farmer's Share } \\
(\mathbf{\%})\end{array}$ \\
\hline 1 & Fatur & 18.000 & 20.000 & 90,00 \\
2 & Prayitno & 18.000 & 21.000 & 85,71 \\
\hline Rata-Rata & $\mathbf{1 8 . 0 0 0}$ & $\mathbf{2 0 . 5 0 0}$ & $\mathbf{8 7 , 8 6}$ \\
\hline
\end{tabular}

Sumber : Analisis Data Primer, 2019.

Tabel tersebut menunjukkan hasil analisis farmer's share pola saluran pemasaran I tingkat. Total rata-rata keseluruhan tingkat farmer's share sebesar 87,86\%. Menurut indikator pengambilan keputusan, pola saluran pemasaran I tingkat adalah efisien. Hal itu disebabkan total rata-rata yang didapat $>50 \%$. Pola saluran pemasaran tingkat II

\section{Kesimpulan}

\section{KESIMPULAN DAN SARAN}

1. Keuntungan yang diperoleh petani jamur merang di Kecamatan Ajung Kabupaten Jember setiap 10 rak per bulan sebesar Rp.1.071.519,54.

2. Pendapatan petani jamur merang di Kecamatan Ajung Kabupaten Jember per skala usaha 10 rak per bulan sebesar Rp. 1.111.688,54.

3. Nilai R/C ratio usahatani jamur merang di Kecamatan Ajung Kabupaten Jember sebesar 2,90 (>1), maka usahatani jamur merang layak diusahakan.

4. Faktor-faktor yang berpengaruh positif dan signifikan terhadap pendapatan usahatani jamur merang yaitu output dengan nilai koefisien regresi sebesar 1,518. Harga jual berpengaruh positif dan signifikan dengan nilai koefisien regresi sebesar 1,455. Faktor pendapatan usahatani jamur merang yang berpengaruh negatif dan tidak signifikan adalah biaya non tunai dengan nilai koefisien regresi sebesar $-0,002$, sedangkan untuk faktor biaya tunai dengan nilai koefisien regresi sebesar $-0,508$ berpengaruh negatif dan signifikan.

5. Hasil analisis farmer's share pola saluran pemasaran I tingkat mendapatkan nilai rata-rata sebesar $87,86 \%$, sedangkan untuk pola saluran pemasaran tingkat II memiliki nilai rata-rata sebesar $69,11 \%$ maka dapat diartikan bahwa pola saluran pemasaran I tingkat lebih efisien dibandingkan dengan pola saluran pemasaran II tingkat.

\section{Saran}

1. Pemerintah maupun petugas penyuluh lapang sebaiknya memberikan penyuluhan terhadap petani jamur merang di Kecamatan Ajung Kabupaten Jember agar dapat membuat perencanaan analisis biaya untuk memaksimalkan pendapatan dan keuntungan yang diperoleh.

2. Pemerintah sebaiknya memberikan perhatian lebih terhadap usahatani jamur merang di Kecamatan Ajung Kabupaten Jember mengingat bahwa usahatani tersebut sangat efisien dan layak diusahakan. Pemberian pelatihan/pembinaan dapat dilakukan terkait manajemen usahatani untuk meningkatkan kemampuan petani dalam berusahatani jamur merang agar semakin banyak masyarakat yang tertarik untuk mengusahakannya.

3. Petani di daerah penelitian sebaiknya lebih mengembangkan usahatani jamur merang dan berusaha menggunakan pola saluran pemasaran I tingkat dengan nilai farmer's share yang cukup tinggi yaitu sebesar $87,86 \%$ karena pada pola saluran pemasaran I tingkat, pemasaran hasil usahatani yang dilakukan para petani lebih efisien dan lembaga pemasaran yang berhubungan langsung dengan para petani jamur merang juga lebih sedikit. 


\section{DAFTAR PUSTAKA}

Agromedia. 2009. Pintar Bertanam Jamur Konsumsi. AgroMedia Pustaka. Jakarta.

Assauri, S. 2007. Manajemen Pemasaran. Rajawali Pers. Jakarta.

Boediono. 1992. Ekonomi Internasional. Seri Sinopsis Pengantar Ilmu Ekonomi Nomor 3. Penertit BPFE. Yogyakarta.

BPS Kabupaten Jember. 2017. Kabupaten Jember Dalam Angka 2017. Badan Pusat Statistik Kabupaten Jember. Jember.

BPS Jawa Timur. 2018. Jawa Timur Dalam Angka 2018. Badan Pusat Statistik Jawa Timur. Jawa Timur

Campbell, N.A. 2003. Biologi Jilid II. Erlangga. Jakarta.

Dahl, D.C. and I, Hammond. 1997. Market and Price Analysis the Agricultural Industries. Mc GrowHill Company. New York.

Genders, R. 1986. Pedoman Berwiraswasta Bercocok Tanam Jamur. Pionin Jaya. Bandung.

Gunawan. A.W. 2000. Usaha Pembibitan Jamur. Penebar Swadaya. Jakarta.

Hagutami, Y. 2001. Budidaya Jamur Merang. Yapentra Hagutani. Cianjur.

Hanafiah, H.M. dan A.M. Saefuddin, 2006. Tataniaga Hasil Perikanan. UI Press. Jakarta.

Hendrik, 2011. Analisis Pendapatan dan Tingkat Kesejahteraan Masyarakat Nelayan Danau Pulau Besar dan Danau Bawah di Kecamatan Dayun Kabupaten Siak Propinsi Riau. Jurnal Perikanan dan Ilmu Kelautan Universitas Riau. Riau.

Herawati, D, 2012. Analisis Tataniaga Nenas Palembang (Kasus Desa Paya Besar, Kecamatan Ogan Ilir, Provinsi Sumatera Selatan). Fakultas Ekonomi dan Manajemen. Institusi Pertanian Bogor. Bogor.

Hernanto, F. 1991. Ilmu Usahatani. Penebar Swadaya. Jakarta.

Himatansi. 2009. All About Jamur Merang. http://www.himatansi.org. Diakses tanggal 1 November 2018.

Kasim, S. A. 2000. Ekonomi Produksi Pertanian. Fakultas Pertanian Unlam. Banjar Baru

Kohls, R.L. dan J.N. Uhl. 1990. Marketing of Agricultural Products. Seventh Edition. Macmillan Company. New York.

Kotler, P. 1997. Manajemen Pemasaran Analisis Perencanaan, Implementasi dan Pengendalian (terjemahan Jaka Wasana). Salemba Empat. Jakarta.

Limbong, W.H dan P. Sitorus. 1987. Pengantar Tataniaga Pertanian. Fakultas Pertanian. Institut Pertanian Bogor. Bogor.

Mawardi, A., dan Hidayani. 2013. Mengenal dan Bertanam Jamur. PT. Putri Pustaka. Bandung. 
Mayun, I. A. 2007. Pertumbuhan Jamur Merang (Volvariella volvaceae) pada Berbagai Media Tumbuh. Jurusan Budidaya Pertanian Fakultas Pertanian Universitas Udayana. Bali.

Mubyarto. 1994. Pengantar Ekonomi Pertanian. LP3ES. Jakarta.

Nurfitasari, I. 2017. Analisis Pendapatan dan Kelayakan Finansial Usahatani Jamur Merang di Desa Mangaran Kecamatan Ajung Kabupaten Jember. Skripsi (Dipublikasi). Universitas Jember. Jember

Nurlailil. 2011. Analisis Keuntungan dan Pemasaran Usahatani Jamur Merang (Volvariella volvaceae) di Kecamatan Wuluhan Kabupaten Jember. Skripsi (Tidak Dipublikasi). Universitas Muhammadiyah Jember. Jember.

Oktaviana, T. 2013. Analisis Pendapatan Usahatani danTataniaga Jamur Merang (Volvariella volvaceae) di Desa Gempol Kolot, Kecamatan Banyusari, Kabupaten Karawang. Skripsi. Institut Pertanian Bogor. Bogor.

Pasaribu, dkk. 2002. Aneka Jamur Unggulan yang Menembus Pasar. Grasindo. Jakarta.

Rahim ABD, Hastuti DRD. 2008. Ekonomika Pertanian Pengantar Teori dan Kasus. Penebar Swadaya. Jakarta.

Ratna, W. 2009. Bunga Rampai Agribisnis Seri Pemasaran. Departemen Agribisnis. Fakultas Ekonomi dan Manajemen. Institut Pertanian Bogor. Bogor

Rismunandar, 1984. Mari Berkebun Jamur. Tarate. Bandung.

Rossi, A. 2011. Kreasi Masakan Jamur Pilihan Plus Pengetahuan Aneka Jamur Pangan \& Analisis Usaha Budidaya dan Kuliner Jamur. G-Media. Yogyakarta.

Samadi, B. 1995. Usahatani Melon. Kanisius. Yogyakarta.

Sinaga, M. 2004. Jamur Merang dan Budidayanya. Penebar Swadaya. Jakarta.

Soekartawi. 1993. Prinsip Dasar: Agribisnis Teori dan Aplikasinya. PT. Raja Grafindo Persada. Jakarta

Soekartawi. 1995. Analisis Usahatani. UI Press. Jakarta.

Sukirno, S. 2000. Makro Ekonomi Modern. PT. Raja Grafindo Perkasa. Jakarta.

Suprapto. 2006. Ilmu Usahatani. Penebar Swadaya. Jakarta.

Suratiyah, K. 2009. Ilmu Usahatani. Penebar Swadaya. Jakarta.

Suriawiria, U. 1997. Bioteknologi Perjamuran. Angkasa. Bandung.

Taufani, A. 2014. Analisis Keuntungan Usahatani Jamur Merang (Volvariella volvaceae) di Kecamatan Jenggawah Kabupaten Jember. Skripsi (Tidak Dipublikasi). Universitas Muhammadiyah Jember. Jember

Thresia, M. 2017. Analisis Pendapatan Usahatani Kedelai di Kecamatan Berbak Kabupaten Tanjung Jabung Timur. Skripsi (Dipublikasi). Institut Pertanian Bogor. Bogor.

Tim Karya Tani Mandiri. 2010. Pedoman Budidaya Jamur. CV.Tunas Aulia. Bandung. 
Tjakrawiralaksana, A. 1985. Usahatani. Jurusan Sosial Ekonomi Pertanian. Fakultas Pertanian. Institut Pertanian Bogor. Bogor

Trubus. 2012. Jamur Merang. Trubus Swadaya. Jakarta.

Widyastuti M. 2002. Kandungan Gizi dan Kegunaan Jamur Tiram. Pusat Pengkajian dan Penerapan Teknologi Bio Industri. Jakarta.

Yulandari, M. 2012. Analisis Sitem Tataniaga Jamur Tiram Putih (Pleurotus ostreatus) Studi Kasus di Desa Kartawangi, Kecamatan Cisarua, Kabupaten Bandung Barat, Jawa Barat). Skripsi (Tidak Dipublikasi). Intitut Pertanian Bogor. Bogor. 